\title{
Conventional Determinants of Corporate Payout Policies in the Egyptian Stock Market
}

\author{
Abdel-Gawad Heba*, Sakr Ahmed, Abdou Rabab \\ Department of Finance, College of Management and Technology, Arab Academy for Science and Technology, Alexandria, Egypt \\ Email: *heba_gawadl@aast.edu
}

How to cite this paper: Heba, A.-G., Ahmed, S., \& Rabab, A. (2021). Conventional Determinants of Corporate Payout Policies in the Egyptian Stock Market. American Journal of Industrial and Business Management, 11, 1089-1112. https://doi.org/10.4236/ajibm.2021.1111066

Received: October 31, 2021

Accepted: November 27, 2021

Published: November 30, 2021

Copyright $\odot 2021$ by author(s) and Scientific Research Publishing Inc. This work is licensed under the Creative Commons Attribution International License (CC BY 4.0).

http://creativecommons.org/licenses/by/4.0/

\begin{abstract}
Corporate Payout policy is one of the interesting topics in corporate finance literature that attracted the attention of many researchers. Despite the extensive research in this area, there is a contradiction between researchers on what are the main determinants of corporate payout policy. Researchers have mainly focused on developed markets and looked at a single dimension of the dividend policy. Therefore, the current study explores the determinants of dividend payout ratio by analyzing the effect of profitability, free cash flow, investment opportunity, liquidity, leverage, firm size and ownership structure on two dimensions of the dividend payout policy: the dividend decision and the payout ratio, taking a sample of all Egyptian listed firms in the period from 2007 till 2020. The results reveal the significance of profitability and investment opportunity on the dividend decision. For the payout ratio model, it is found that free cash flow, profitability and managerial ownership are significant determinants of payout ratio. Finally, by analyzing the dividend-paying firms, the results reveal that financial leverage affects the payout ratio of these firms.
\end{abstract}

\section{Keywords}

Dividend Policy, Dividend Decision, Dividend Payout Ratio, Egypt

\section{Introduction}

Successful corporation generates net income after deducting all kinds of expenses. The company utilizes this net income for various purposes like acquiring new assets, repayment of outstanding debt, repurchase of outstanding common stock as well as distribution among shareholders. When a corpora- 
tion decides to distribute their net income to shareholders, it is called dividend.

The dividend policy has been an issue of interest in the financial literature since long time. Miller and Modigliani (1961) initiate the irrelevancy theory which is based on perfect market assumptions. However, the real world does not always work as predicted by a mathematical model. Investors may care about dividends for reasons explained by tax incentives, clientele effect or agency problem purposes (Ozuomba et al., 2016). Today, there is a great agreement on the relevance of dividend to firm value, but the main determinants of dividend payout ratios remain highly questionable and this is exactly why it's called the dividend puzzle (Black, 1976).

The dividend puzzle is still debatable and has many interesting areas to be explored specially in developing markets because of the unique nature of these markets and their instabilities. The macro-economic conditions surrounding firms in these countries such as the political or the economic situation, could let them change their investment and financing plan (Glen et al., 1995). Moreover, developing countries are characterized with poor corporate governance which means that they suffer from agency problem to some extent, therefore, studying the payout policy is important as it helps in reducing the agency problem by monitoring managers behavior (Easterbrook, 1984).

This study mainly focuses on the propensity to pay dividends as well as the dividend payout ratio and to conclude if they have the same determinants or not. Unlike most of previous studies that either focus on the determinants of dividend decision only such as Fama and French (2001), De Angelo et al. (2006) and Denis and Osobov (2008) and Takmaz et al. (2020) or the payout ratio only such as Kania and Bacon (2005), Amidu and Abor (2006), Thanatawee (2011) and Mehdi et al. (2017).

This study also focuses mainly on the Egyptian stock market which is considered as one of the emerging markets and thus it provides an out-of-sample test for previous research that focuses mainly on developed markets. Furthermore, the sample period if this study is very rich as it includes a serious of political and economic events that affected the Egyptian stock market such as the Global Financial Crisis in 2008, the Egyptian revolutions in 2011 and 2013, the floatation of the Egyptian pound in 2016 and finally the widespread of Coronavirus in 2019 and 2020. Thus, this rich sample period enables the researchers to analyze the determinants of payout policy in a highly fertile sample period with different up and down trends.

The rest of the paper is organized as follows: Section 2 presents a literature review providing the theoretical framework and the previous studies of the determinants of payout policy. Section 3 identifies the collected data and the followed methodology. Section 4, the empirical findings are discussed and analyzed. Section 5 , the concluding recapitulates the main findings and finally section 6 , highlights the recommendations and limitations of the study. 


\section{Literature Review}

\subsection{Theories of Corporate Payout Policy}

Dewasiri and Weerakoon (2016) highlight that a single theory or determinant is unlikely to explain the dividend policy alone. Some common theories explaining payout policy are as follows:

- The Bird in Hand Theory: It's initially developed by Lintner (1956) and Gordon (1959) and it clarifies that investors will often tend to favor cash in hand, dividends, to a future promise of capital gain, retained earnings, because of uncertainty of future cash flow and minimization of risk.

- Agency theory: Easterbrook (1984) states that when a company pays out cash to its investors that could have been used to fund new investments, it should finance its investment by accessing the capital market comparing to other firms that do not pay dividends and therefore this reduces the agency problem.

- Free Cash Flow Theory: Developed by Jensen (1986) and it explains that a dividend and debt interest payment reduce the free cash flow and controls the cash available to managers (Fairchild, 2010), and therefore reduces the opportunity for overinvestment.

- Tax preference theory: For tax-related reasons, investors prefer retained earnings over the distribution of cash dividends. As a result of the tax advantage of capital gains, investors may prefer a low dividend payout as opposed to a high payout (Brennan, 1970). In Egypt taxes on dividends and capital gains were imposed only starting 2014, therefore this theory is not applicable in our study.

- Signaling theory: As reported by Bhattacharya (1979) firm with an advanced level of asymmetric information will have to pay a higher level of dividends to signal the same level of earnings as a firm with a lower level of asymmetric information.

- Pecking order theory: The POT suggests that in the face of a semi-strong efficient market, firms decide to finance new investments or dividends with retained earnings or internal sources over external sources of finance Myers (1984), and Majluf and Myers (1984).

- Life cycle theory: According to Garengo et al. (2007) and O'Connor and Byrne (2015) as a company matures, its capability to generate cash go beyond its capability to invest in profitable projects. According to this theory, the best strategy is for the firm to distribute its free cash flow to shareholders using dividends.

\subsection{Determinants of Payout Policy}

This section presents all the studied determinants of payout policy, supported by previous studies and the research hypotheses are formulated based on the corporate payout theories mentioned in section 1 and the previous studies. 


\subsubsection{Profitability}

According to the life cycle theory, mature, profitable companies distribute dividends. Nevertheless, companies that do not pay dividends are not necessarily unprofitable. If a company thinks that its own growth opportunities are better than investment opportunities available to shareholders elsewhere, the company should keep the profits and reinvest them into the business.

Most of previous studies found a positive relationship between profitability and payout policy like: Al-Malkawi (2007), Bokpin (2011), Abdelsalam and El-Masry (2008) and Dewasiri et al. (2019).

Therefore, following the life cycle theory and the supported previous studies, the first Hypothesis is formulated:

H1: There is a significant positive relationship between payout policy and profitability.

\subsubsection{Investment Opportunity}

According to the pecking order theory, if the company has any residual earnings after financing all investment opportunities, this profit could be distributed to shareholders in cash dividends, since the company usually depends first on its internal sources in financing new investments, otherwise the company will not pay dividends (Amidu \& Abor, 2006). Most of previous studies support this negative relationship such as Abor and Bokpin (2010), Dewasiri et al. (2019), Imamah et al. (2019) and Khana et al. (2020).

Based on the pecking order theory and the supporting studies, we can predict the following:

H2: There is a significant negative relationship between investment opportunity and dividend payout policy.

\subsubsection{Free Cash Flow}

According to free cash flow hypothesis of Jensen (1986), one of the ways that firms can use to control the agency problem that arises due to having large amount of free cash flows is through paying dividends to shareholders rather than leaving these cash flows for managers who can use it in an inefficient way leading to high agency costs. This argument is supported by many authors such as Thanatawee (2011). Thus, the following hypothesis is formulated.

H3: There is a significant positive relationship between cash flow and dividend payout policy.

\subsubsection{Leverage}

Rozeff (1982) conveys that firms having high financial leverage tend to have low payouts ratios, to decrease transaction costs linked with external financing. Moreover accrding the free cash flow hypothesis of Jensen (1986), both dividends and debts act as a subsitue for monitoring the free cash flow available to managers. Most of previous studies support this point of view such as Setiawan et al., (2016), Ranajee and Pathak (2018), Wahjudi (2019) and Basri (2019). 
Thus after discussing the free cash flow hypothesis that was supported by many previous studies, the following hypothesis is formulated:

H4: There is a significant negative relationship between leverage and dividend payout policy.

\subsubsection{Liquidity}

Baker et al. (1985) state that liquidity is the main determinant of dividend policy. The company's ability to pay dividends increase when their overall cash position and liquidity are stronger, moreover according to the agency theory firms with high liquidity choose to distribute dividends to avoid any agency problems. Previous studies looked intensively in this area and supported this positive relationship such as Khan et al. (2011) and Kumar and Waheed (2015).

Based on the agency and its above-mentioned supporting studies, the following hypothesis is expected:

H5: There is a significant positive relationship between liquidity and dividend payout policy.

\subsubsection{Firm Size}

According to the life cycle theory, early in the life cycle, firms are likely to assign their incomes in reinvesting activities to improve their growth. In contrast, when firms mature, they have a tendency to distribute their incomes to investors as dividend (Denis \& Osobov, 2008).

Most of previous studies support the above explanation of this relationship such as Al-Malkawi (2007), Yusof and Ismail (2016) and Takmaz et al. (2020).

Following the life cycle theory as well as the previous studies, the following hypothesis is formulated:

H6: There is a significant positive relationship between firm size and dividend payout policy.

\subsubsection{Ownership Structure}

The type of owners inside the company as well as the distribution of ownership stakes undoubtedly have an impact on the performance of firms and the reduction of agency costs in the firm. As explained before dividend policy could help as well to mitigate the agency problem and therefore substitute the role of ownership structure in this issue. Many scholars have studied the effect of ownership structure on dividend payout policy.

The first variable of ownership structure studied in this research is Institutional ownership. Jensen and Meckling (1976) claim that the agency costs may be restricted by institutional investors due to their monitoring role, so no need for dividends as a way to mitigate agency problem. This negative relationship is supported by Al-Najjar \& Kilincarslan (2016).

The second ownership structure variable used in this study is managerial ownership. According to the agency theory, the more significant the managerial ownership is, the more shareholding managers will be interested to pursue more 
profitable projects and accordingly decrease dividends. This explanation is supported by Al-Qahtani \& Ajina (2017) and Gul et al. (2020).

The last ownership structure variable is free float ownership, the agency theory, Easterbrook (1984), Jensen (1986) and Rozeff (1982) argue that dividend offers indirect advantage of control to individual owners where active monitoring of a firm's insiders by its shareholders is missing (Rozef, 1982), Therefore, the theory predicts a positive relationship between free float and payout policy.

From the above discussion on the agency theory and the previous studies supporting it, the following hypotheses on ownership structure are formulated:

H7a: There is a significant negative relationship between institutional ownership and dividend payout policy.

$H 7 b$ : There is a significant positive relationship between managerial ownership and dividend payout policy.

H7c. There is a significant negative relationship between managerial ownership and dividend payout policy.

\section{Data and Methodology}

\subsection{Variables Description and Calculations}

Table 1 shows the research variables and their calculations:

\subsection{Research Models and Research Methods}

Given the above Hypotheses, the research model used to test these hypotheses is: First the descriptive statistics such as mean, maximum, minimum and standard deviation to describe first the variables used in this study, and then regression analysis is conducted. We have two models, the first which ha dividend decision as dependent variable which is a dichotomous variable so it is tested using the logistic regression. Second model tests the determinants of the payout ratio and the GLS random effect regression for panel data is conducted based on the insignificance of the Hausman test. The statistical techniques are carried out using the STATA 17.0 software. Following the lead of Jabbouri (2016), Chazi et al. (2018); Dewasiri et al. (2019), Trabelsi et al. (2019); Baker et al. (2019); Byun et al. (2021), Bilel and Mondher (2021), the following are the logistic regression and the GLS random effect regression equations respectively:

$$
\begin{aligned}
& \text { Div__Decision }_{i, t}=\alpha+\beta 1 \text { Prof }_{i, t}+\beta 2 \mathrm{FCF}_{i, t}+\beta 3 \mathrm{LIQ}_{i, t}+\beta 4 M B_{-} \text {ratio }_{i, t} \\
& +\beta 5 \text { Lev }_{i, t}+\beta 6 F S_{i, t}+\beta 7 \text { Inst_own }_{i, t}+\beta 8 M a n_{-} O w n_{i, t} \\
& +\beta 9 \text { Free_Float }{ }_{i, t}+\mu_{i, t} \\
& \text { Payout_Ratio } i_{i, t}=\alpha+\beta 1 \text { Prof }_{i, t}+\beta 2 F C F_{i, t}+\beta 3 L I Q_{i, t}+\beta 4 M B \_ \text {ratio } o_{i, t} \\
& +\beta 5 \text { Lev }_{i, t}+\beta 6 F S_{i, t}+\beta 7 \text { Inst_own }_{i, t}+\beta 8 M a n_{-} O w n_{i, t} \\
& +\beta 9 \text { Free_Float }{ }_{i, t}+\mu_{i, t}
\end{aligned}
$$

\subsection{Sampling and Data Collection}

All the data used in this research is collected from secondary sources, and the 
Table 1. Variables description and calculations.

\begin{tabular}{|c|c|c|c|}
\hline Variables & Indicators & Measurement & Reference \\
\hline \multicolumn{4}{|c|}{ Dependent variables } \\
\hline $\begin{array}{l}\text { Dividend } \\
\text { Decision }\end{array}$ & DIVDECISION & $\begin{array}{l}\text { Coded " } 1 \text { " if the firm } \\
\text { paid dividend or " } 0 \text { " } \\
\text { if it didn't. }\end{array}$ & $\begin{array}{l}\text { Budiarso et al. (2019), Dewasiri et al. (2019), } \\
\text { Trabelsi et al. (2019), ELbannan (2020) and } \\
\text { Takmaz et al. (2020) }\end{array}$ \\
\hline $\begin{array}{l}\text { Dividend } \\
\text { Payout Ratio }\end{array}$ & DIVRATIO & $\frac{\text { Dividend Per Share }}{\text { Earnings Per Share }}$ & $\begin{array}{l}\text { Neves (2017), Jabbouri (2016), } \\
\text { Dewasiri et al. (2019) and } \\
\text { Byun et al. (2021) }\end{array}$ \\
\hline
\end{tabular}

\section{Independent variables}

Profitability Prof

Free Cash flow

FCF

Liquidity

LIQ

Current Assets - Current Liabilities

Cash flow from operation - Capital expenditures

\section{Investment}

Opportunity

Leverage

Firm Size

Institutional

Ownership

Managerial

Ownership

Free Float
LEV

FS

Log T.Assets

INST_OWN

Man_Own

M/B ratio

Market value Per Share/Book Value Per

Share

Total Shares held by Institutions Total captial shares

Total Shares held by top management Totalcaptial shares

Total Shares held by external investors Totalcaptial shares
S.T Debts/T.assets.
Patra et al. (2012),

Al-Kayed (2017), Budagaga (2020)

Al-Malkawi (2007),

Ahmed (2015), Chazi et al. (2018)

Trabelsi et al. (2019), ELbannan (2020)

Patra et al. (2012)

and Al-Kayed (2017),

Dewasiri et al. (2019)

Ramadan (2015),

Setiawan et al. (2016),

Ranajee and Pathak (2018)

Ramadan (2015); Jabbouri (2016);

Baker et al. (2019);

Dewasiri et al. (2019) and

Byun et al. (2021)

Al-Najjar \& Kilincarslan (2016),

Sindhu et al. (2016),

Dhuhri and Diantimala (2018)

Sakir \& Fadli (2014),

Sindhu et al. (2016)

and Dhuhri and Diantimala (2018)

Abdelsalam and El-Masry (2008) and

Afza and Mirza (2010) 
main source of the research data is Bloomberg Database and annual reports (for some missing data) that were purchased from the Egyptian Company for Information Dissemination (EGID) in order to have a balanced panel data set and avoid any survivorship bias. The sample includes 175 Egyptian listed firms. It's worth mentioning that the Bloomberg terminal developed that was launched in 1981, is one of the main product offerings from Bloomberg L.P. It delivers fast access to crucial news and historical financial data about listed firms all over the world. The choice of 175 firms is mainly due to the fact that some of listed firms in the Egyptian stock market are inactive as shown in Table 2 and thus these firms are removed from the sample as they do not have consistent data for 6 consecutive years. It is shown in the appendix the name of excluded firms. Moreover, financial companies such as banks and insurance companies are excluded from the sample, since they follow different disclosure requirements and corporate governance procedures (Baker \& Wurgler, 2004). As was mentioned in the Section 1, the sample period for this study covers from 2007 to 2020 which is a rich sample period that includes several political and economic events.

\section{Findings and Analysis}

\subsection{Descriptive Statistics}

Table 3 illustrates the descriptive statistics of all the variables used in this study: Profitability, free cash flow, investment opportunity, liquidity, leverage, firm size, managerial ownership, institutional ownership, free float ownership, dividend payout ratio and the dividend decision for the whole sample and for payers and non-payers to explore any potential significant differences in means for each of the variables between these two types of firms using the t-test which will help better understand the characteristics of the dividend paying firms.

Looking at the whole sample, we can see that Egyptian listed firms in our sample have on average a positive free cash flow, which could be used as internal source of finance for firms having a good investment opportunity. They also have high investment opportunity, which should be the case for any emerging market, as they are usually characterized with their continued growth and profitability (Walsh et al., 2005). Egyptian firms are not very highly levered as the mean is $37 \%$. As for the liquidity, it shows a mean of 2.9 which is within the ideal rule of thumb that the current ratio should range between 1 and 2 (Panigrahi, 2013).

Table 2. Listed Versus Traded firms on EGX.

\begin{tabular}{|c|c|c|c|c|c|c|c|c|c|c|c|c|c|c|}
\hline & 2007 & 2008 & 2009 & 2010 & 2011 & 2012 & 2013 & 2014 & 2015 & 2016 & 2017 & 2018 & 2019 & 2020 \\
\hline No of listed firms & 435 & 373 & 306 & 212 & 213 & 213 & 212 & 212 & 221 & 222 & 222 & 220 & 218 & 215 \\
\hline No of traded firms & 337 & 322 & 289 & 211 & 204 & 204 & 206 & 206 & 217 & 213 & 213 & 218 & 213 & 214 \\
\hline
\end{tabular}

Source: EGX Annual Reports (2007-2020). 
Table 3. Descriptive statistics.

\begin{tabular}{|c|c|c|c|c|c|c|c|c|c|c|c|c|c|c|c|}
\hline \multirow{2}{*}{ Variables } & \multirow[b]{2}{*}{ Mean } & \multicolumn{2}{|c|}{ Payers } & \multicolumn{6}{|c|}{ Non-Payers } & \multicolumn{6}{|c|}{ Whole Sample } \\
\hline & & SD & Min & $\operatorname{Max}$ & Mean & SD & Min & $\operatorname{Max}$ & t-statistics & Mean & SD & Min & $\operatorname{Max}$ & Skewness & Kurtosis \\
\hline MB ratio & 1.4463 & 0.9413 & 0.4276 & 6.0120 & 1.2819 & 0.8405 & 0.4276 & 6.0120 & $-5.9509^{* * *}$ & 1.3979 & 0.9215 & 0.4276 & 6.0120 & 2.5865 & 11.1702 \\
\hline Lev & 0.3607 & 0.2093 & 0.0159 & 1.4430 & 0.3757 & 0.2994 & 0.0159 & 1.4430 & 1.2837 & 0.37125 & 0.25173 & 0.0159 & 1.4430 & 1.3169 & 5.9275 \\
\hline Liq & 2.5978 & 4.3054 & 0.2154 & 39.7841 & 3.6025 & 7.2296 & 0.2154 & 39.7841 & $3.8572^{* * *}$ & 2.8693 & 5.3454 & 0.21548 & 39.7841 & 5.2788 & 33.1252 \\
\hline Prof & 0.1029 & 0.0942 & -0.2582 & 0.3627 & -0.0023 & 0.1056 & -0.3381 & 0.3089 & $-22.0854^{* * *}$ & 0.0697 & 0.1089 & -0.33812 & 0.36272 & -0.2562 & 5.2642 \\
\hline FS & 2.0121 & 0.6720 & 0.5040 & 3.6552 & 1.61 & 0.7524 & 0.5040 & 3.6552 & $-11.9496^{* * *}$ & 1.8893 & 0.7144 & 0.5040 & 3.6552 & 0.2636 & 2.5770 \\
\hline Inst_Own & 0.1157 & 0.2306 & 0 & 0.9465 & 0.1109 & 0.2043 & 0 & 0.9465 & -0.4450 & 0.1188 & 0.2337 & 0 & 0.9465 & 2.3630 & 7.4679 \\
\hline Free_Float & 0.4018 & 0.2367 & 0.0205 & 0.9398 & 0.4445 & 0.2481 & 0.0205 & 0.9398 & $3.4639^{* * *}$ & 0.4029 & 0.2390 & 0.05058 & 0.9398 & 0.3900 & 2.2826 \\
\hline Div_Ratio & & & & & & & & & & 0.4333 & 0.9166 & -2.0453 & 6.290986 & 3.281546 & 21.49474 \\
\hline DIVDECISION & & & & & & & & & & 0.7037938 & 0.4566941 & 0 & 1 & -.8926909 & 1.796897 \\
\hline No of Observati ons & & & 1715 & & & 73 & 35 & & & & & 24 & 50 & & \\
\hline
\end{tabular}

This table shows the Descriptive Statistics for the conventional variables as well as the dependent variables used in the study during the period 2007-2020 for a total of 2450 observations for the whole sample, 1715 for payers and 735 for non payers. FCF is the free cash flow measured as cash flow from operations minus capital expenditures, MB ratio is the investment opportunity measured as market value per share divided by book value per share, LEV is leverage measured as S.T Debts divided by total assets, LIQ is liquidity measured as current assets divided by current liabilities, profitability is measured as EBIT divided by Total Assets, FS is Firm Size measured as Log of Total Assets, INST_ONW is the percentage of institutional ownership, MAN_OWN is the percentage of managerial ownership and finally FREE_FLOAT is the percentage of free float. As for the dependent variables; DIVRATIO is the dividend payout ratio measured as total cash dividends divided by earnings per share; DIVDECISION is the dividend decision that take value of 1 in case of dividend distribution and 0 otherwise. Notes: All variables are winsorized at 99 percent levels. The $\mathrm{t}$-statistics column report any significant difference in means of conventional variables between payers and non-payers. ${ }^{* * *}$ $* *$, ${ }^{*}$ indicate statistical significance at the $1 \%, 5 \%$, and $10 \%$ levels, respectively.

The average profitability of Egyptian firms is 7\%, with a maximum value of $36 \%$ and a minimum value of $-33 \%$. This high fluctuation in profitability reflects the wide variety of events that affected the firms during the sample period. Moreover, firms size shows that firms in the sample has a mean of almost 2 and the maximum value is almost 4 . Furthermore, the ownership structure variables show that the highest type of ownership is free float, followed by institutional ownership and finally the managerial ownership. As for the dependent variables, the payout ratio shows an average of $43 \%$ which means that firms usually prefer to retain more earnings rather than distributing dividends, this could reflect the tendency of Egyptian firms to depend on internal financing in their capital structure due to the high interest rates in Egypt during the sample period.

Finally the Skewness and Kurtosis value of all the independent variables show that most of the variables are not normally distributed but according to Gauss-Markov theorem, which indicates in order to get "best linear unbiased estimators" (BLUE); errors should be uncorrelated and their mean is zero and they show homo-scedasticity. Therefore, the normality assumption is not essential to 
obtain BLUE results (Schmidt \& Finan, 2018).

The second part of Table 3 shows a comparison of the variables between payers and non-payers using the t-test. All the independent variables (free cash flow, profitability, investment opportunity, liquidity, firm size, free float ownership and managerial ownership) show a significant difference between payers and non-payers except leverage and institutional ownership. Dividend paying firms are found to be more profitable, with higher free cash flow, higher investment opportunity, lower liquidity, bigger in size, with lower managerial ownership and higher free float.

\subsection{Regression Analysis}

\subsubsection{Logistic Regression}

Before conducting the logistic regression, some diagnostics are done first. The linearity of the independent variables and the log odds is checked using the linktest and as shown in Table 4, and the results reveal that there is no misspecification error. Next the multicollinearity is checked and as shown in Table 5, there is no multicollinearity problem. Finally, the Hausman test is done to see which model to use random effect or fixed effect and the Hausman test is significant which means rejecting the null hypothesis that the model is random and therefore a fixed effect logistic regression is conducted. Since the Hausman test is significant, this could mean that the model suffers from an endogeneity problem so to mitigate this problem all variables are lagged at period t-1 (Elbannan, 2020).

Table 6 presents the results of the logistic regression, Model 1 tests the effect of the conventional variables (free Cash flow, investment opportunity, profitability, firm size, liquidity, leverage, managerial ownership, free float and institutional ownership). Model 2 tests the same relationship but firms having negative equity are excluded as these firms are usually financially distressed and characterized with high default risk and since they constitute only $3 \%$ of the whole sample so their omission will not influence the results (Budiarso et al., 2019). The following are the results after doing the HAC estimator "Heteroskedasticity and autocorrelation consistent estimator" to overcome any heteroskedasticity or autocorrelation problems that might appear in the model.

Table 4. Linktest for specification error.

\begin{tabular}{ccccccc}
\hline Dividend Decision Coefficient & Std. error & $\mathrm{Z}$ & $\mathrm{P}>|\mathbf{z}|$ & \multicolumn{2}{c}{ [95\% conf. interval] } \\
\hline _hat & 0.9718 & 0.1139369 & 8.53 & 0.000 & 0.7485 & 1.195142 \\
_hatsq & 0.0201 & 0.0545535 & 0.37 & 0.712 & -0.0868036 & 0.1270423 \\
_cons & -0.0092 & 0.104193 & -0.09 & 0.929 & -0.2134399 & 0.1949891
\end{tabular}

This table shows the Linktest that is used to check if the logistic regression used to test the effect of the dividend decision o nthe conventiontional variables (FCF, liquidity, leverage, firm size, investment opportunity, Free float, Managerial ownership and institutional ownership) suffers from any specifications error. 
Table 5. Checking multicollinearity.

\begin{tabular}{ccc}
\hline Variable & VIF & $1 /$ VIF \\
\hline Liq & 1.38 & 0.73 \\
Lev & 1.30 & 0.77 \\
Prof & 1.26 & 0.79 \\
FS & 1.21 & 0.83 \\
FCF & 1.19 & 0.84 \\
MB_ratio & 1.05 & 0.95 \\
Free Float & 1.12 & 0.90 \\
Man_Own & 1.02 & 0.98 \\
Inst_Own & 1.09 & 0.92 \\
\hline
\end{tabular}

Tolerance and VIF and used to check if there is any linear combination between the independent variables of the model; liq (Liquidity), Lev (Leverage), Prof (Profitability), FS (firm size), FCF (free cash flow), MB ratio (investment opportunity), Free float (Free float ownership), Man_own (Managerial ownership and Inst_own (Institutional ownership).

Table 6. Logistic regression analysis.

\begin{tabular}{|c|c|c|c|c|}
\hline \multicolumn{5}{|c|}{ Dividend Decision } \\
\hline & \multicolumn{2}{|c|}{ Model 1} & \multicolumn{2}{|c|}{ Model 2} \\
\hline Prob > Chi2 & \multicolumn{2}{|c|}{$0.0001^{\star * *}$} & \multicolumn{2}{|c|}{$0.0245^{\star *}$} \\
\hline Hausman Test & \multicolumn{2}{|c|}{$0.0000^{* * *}$} & \multicolumn{2}{|c|}{$0.0000^{* * *}$} \\
\hline No of Obervations & \multicolumn{2}{|c|}{2450} & \multicolumn{2}{|c|}{2383} \\
\hline Variables & Coefficient & $\mathrm{P}|\mathrm{z}|$ & Coefficient & $\mathrm{P}|\mathrm{z}|$ \\
\hline FCF & 0.0007516 & 0.883 & 0.0003786 & 0.940 \\
\hline MB_Ratio & $-0.3902538^{\star}$ & 0.075 & $-0.3799588^{*}$ & 0.077 \\
\hline Prof & $4.673493^{\star *}$ & 0.041 & 4.581324 & $0.046^{* *}$ \\
\hline FS & 0.3852429 & 0.391 & 0.3359773 & 0.442 \\
\hline Liq & -0.0100147 & 0.821 & -0.0070843 & 0.872 \\
\hline Lev & -2.924858 & 0.137 & -2.559422 & 0.190 \\
\hline Man_Own & 0.1532954 & 0.974 & 0.079425 & 0.986 \\
\hline Free_Float & -1.058464 & -3.179377 & -0.9064846 & 0.400 \\
\hline Inst_Own & 0.1015486 & 0.926 & 0.0943738 & 0.929 \\
\hline
\end{tabular}

This table shows the results of the logistic regression which tests the effect of the conventional variables namely; FCF free cash flow, MB_Ratio Investment Opportunities, Prof Profitability, FS Firm Size, Liq Liquidity, Lev Leverage, Man_Own Managerial Ownership, Free_Float free float ownership, Inst_Own Institutional Onwership, and their effect on the dividend decision. Shown in the table the coefficients of each variables and the $\mathrm{P}$ values. Model 1 is the full sample and Model 2 excludes from the sample firms with negative equity. ${ }^{* *},{ }^{* *},{ }^{*}$ indicate statistical significance at the $1 \%, 5 \%$, and $10 \%$ levels, respectively. 
As for the results, free cash flow, firm size, liquidity, leverage, managerial ownership, free float and institutional ownership show an insignificant relationship with the dividend decision which means that these variables do not have an impact on the company's decision of whether to distribute dividends or not.

The only two variables that show a significant relationship with dividend decision are: investment opportunity, which shows a significant negative relationship at a significance level of $10 \%$ which supports the second research hypothesis $\mathrm{H} 2$. This could be explained through the pecking order theory which states that firms pay dividends only when they have residuals after financing all their investment opportunities since they should depend first on internal sources of finance. The results are consistent with many previous studies Abor and Bokpin (2010), Dewasiri et al. (2019), Imamah et al. (2019) and Khana et al. (2020).

Relating this result to the Egyptian context, this could be due to the fact that external financing is not easy in the Egyptian market as the stock market passed in the sample period with many crashes, starting from the Global Financial Crisis in 2008, followed by the Egyptian revolution of 2011, where main indices of Egypt's stock exchange (EGX 30 and EGX 100) both fell by $10.5 \%$ and $14 \%$ respectively, then the devaluation of the currency in 2016 and finally the outrage of Coronavirus when the Egyptian exchange lost around LE 134.1 billion of its market capitalization (OECD, 2020). Hence the equity issues as a financing option is not easy in Egypt due to recent stock market crashes.

Moreover, the lending rate of banks in Egypt is increasing ever since the revolution of 2011 as shown in Figure 1, it increased to 12\% and reached 13\% in 2016 and then it jumped to $18 \%$ in 2017 and 2018 and then started decreasing again. So overall we can say that external financing in Egypt is costly whether it is through the stock market or bank loans. This can justify why firms in Egypt depend first on internal sources whenever there is an investment opportunity and dividends are considered residual.

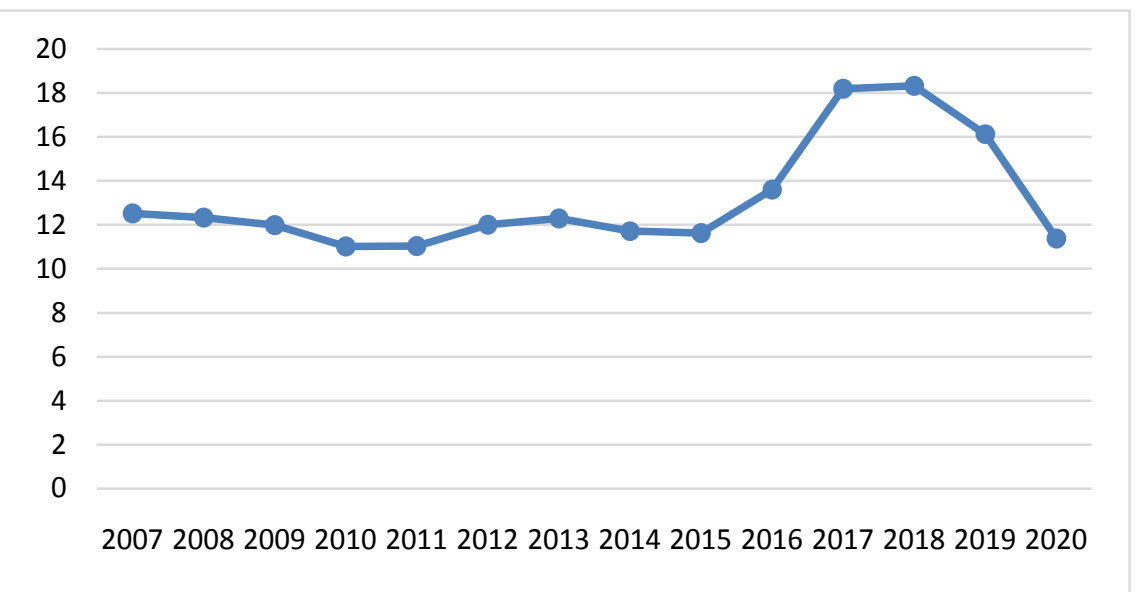

Figure 1. Lending rates in Egypt (Source: World Bank). 
Profitability also tends to be one of the significant determinants of payout policy in Egypt. It shows a significant positive relationship which supports the first hypothesis H1. These results are in line with the life cycle theory that the more mature firms get, the more profitable they are and therefore, the less investment opportunities they have and consequently the higher their dividends (Ahmed, 2013).

This result is consistent with a lot of previous studies such as Fama and French (2001), Al-Malkawi (2007), Bokpin (2011), Abdelsalam and El-Masry (2008), Dewasiri et al. (2019).

Relating this to the Egyptian context, this could have the same explanation of investment opportunity that whenever firms are having investment opportunity, they will rely more on internal sources of finance, since external sources are costly and therefore they cannot afford to distribute dividends but when firms mature that have less investment opportunities and become more profitable therefore, they decide to payout dividends to investors.

As for Model 2, no change on the results were found, which means that firms having negative equity did not cause any distortion in the data.

\subsubsection{GLS Regression}

After testing the effect on conventional variables on dividend decision using the logistic regression. In this section, Models 1 and 2 are tested again but using payout ratio as a dependent variable. Furthermore, in this section Model 3 is added in which firms that have payout ratio less than zero or more than 1 are excluded from the sample. This is mainly due to the fact that healthy firms have payout ratio that reflect their real earnings instead of "cooking books" or in other words paying out earnings that they don't have (Harackiewicz et al., 2002). Therefore, firms realizing net loss and paying out dividends and firms paying out dividends more than their realized earnings are excluded from the sample; these firms constitute almost $16 \%$ of the sample.

Since this study uses panel data, Hausman test is conducted to determine whether fixed effects or random effects models should be used. Given the results of Table 7, the Hausman test is insignificant for the 3 models under investigation and thus random effects model should be used. The following are the results after doing the HAC estimator "Heteroskedasticity and Autocorrelation Consistent Estimator" to overcome any heteroskedasticity or autocorrelation problems that might appear in the model.

The results of Table 7 show that three variables have a significant relationship with payout ratio which are: free cash flow, profitability and managerial ownership. First, free cash flow shows a significant negative relationship with the payout ratio, although it was insignificant in the logistic regression model which means that it is not necessary in the decision to distribute or not but it does influence the increase and decrease of dividend. These results contradict the third hypothesis $\mathrm{H} 3$ that predicts that there is a significant positive relationship between free cash flow and the payout policy but it is consistent with some pre- 
vious studies such as Afza and Mirza (2010).

A justification of this result is provided by Deng et al. (2013) who argue that in an imperfect market where there are some restrictions on the external sources of finance, firms choose to keep the free cash flow and cut or decrease dividends and this could be their only source of finance. This Justification perfectly matches the Egyptian market since it is described by Metwally and Darwish (2015) as an inefficient and as described in the section 4.2.1 that external sources of finance face a lot of restrictions in the Egyptian market.

Lastly, managerial ownership shows a significant positive relationship with payout ratio; this contradicts the agency theory that states that managerial ownership could be a significant tool for good governance since they are responsible on the financial decision inside the company, therefore they should invest in profitable projects and hence decrease dividends.

Table 7. GLS Random effect model.

\begin{tabular}{|c|c|c|c|c|c|c|}
\hline \multicolumn{7}{|c|}{ Payout Ratio } \\
\hline & \multicolumn{2}{|c|}{ Model 1} & \multicolumn{2}{|c|}{ Model 2} & \multicolumn{2}{|c|}{ Model 3} \\
\hline Prob > Chi2 & \multicolumn{2}{|c|}{$0.0317^{\star *}$} & \multicolumn{2}{|c|}{$0.0091^{\star * *}$} & \multicolumn{2}{|c|}{$0.03362^{\star *}$} \\
\hline $\begin{array}{c}\text { Hausman } \\
\text { Test }\end{array}$ & \multicolumn{2}{|c|}{0.9389} & \multicolumn{2}{|l|}{0.9569} & \multicolumn{2}{|c|}{0.7456} \\
\hline $\begin{array}{c}\text { No of } \\
\text { Observations }\end{array}$ & \multicolumn{2}{|l|}{2450} & \multicolumn{2}{|l|}{2383} & \multicolumn{2}{|l|}{2058} \\
\hline Variables & Coefficient & $P|z|$ & Coefficient & $\mathbf{P}|\mathbf{z}|$ & Coefficient & $\mathbf{P}|\mathbf{z}|$ \\
\hline FCF & $-0.0016^{\star *}$ & 0.022 & $-0.0015539^{\star *}$ & 0.024 & 0.0002742 & 0.521 \\
\hline MB_Ratio & 0.00049 & 0.986 & 0.0009829 & 0.972 & -0.006261 & 0.651 \\
\hline Prof & $1.08272^{\star * *}$ & 0.001 & $1.0708^{\star * *}$ & 0.001 & -0.1009263 & 0.591 \\
\hline FS & 0.04868 & 0.365 & 0.0601805 & 0.295 & -0.0014435 & 0.964 \\
\hline Liq & 0.00197 & 0.821 & 0.0021939 & 0.807 & -0.0026162 & 0.550 \\
\hline Lev & -0.1440 & 0.627 & -0.1415158 & 0.673 & $-0.26849^{* * *}$ & 0.008 \\
\hline Man_Own & $0.63860^{* *}$ & 0.048 & $0.63512^{\star * *}$ & 0.045 & -0.0908973 & 0.679 \\
\hline Free_Float & 0.03248 & 0.801 & 0.0397266 & 0.764 & 0.0441764 & 0.578 \\
\hline Inst_Own & 0.28345 & 0.386 & 0.2686506 & 0.401 & -0.1202179 & 0.119 \\
\hline
\end{tabular}

This table shows the results of the GLS random effect regression which tests the effect of the conventional variables namely; FCF free cash flow, MB_Ratio Investment Opportunities, Prof Profitability, FS Firm Size, Liq Liquidity, Lev Leverage, Man_Own Managerial Ownership, Free_Float free float ownership, Inst_Own Institutional Onwership, and their effect on the payout ratio. Shown in the table the coefficients of each variables and the P-values. Model 1 is the full sample, Model 2 excludes from the sample firms with negative equity and Model 3 includes only paying firms having a payout ratio higher than 0 and less than $1 .{ }^{* *},{ }^{* *},{ }^{\star}$ indicate statistical significance at the $1 \%, 5 \%$, and $10 \%$ levels, respectively. 
Table 8. Summary of research hypotheses results.

\begin{tabular}{|c|c|}
\hline Hypothesis & Result \\
\hline H1: There is a significant positive relationship between payout policy and profita-bility. & Supported \\
\hline $\begin{array}{l}\text { H2: There is a significant negative relationship between investment opportunity and dividend payout } \\
\text { policy. }\end{array}$ & Supported \\
\hline H3: There is a significant positive relationship between cash flow and dividend payout policy. & Partially Supported \\
\hline H4: There is a significant negative relationship between leverage and dividend payout policy. & Supported \\
\hline H5: There is a significant positive relationship between liquidity and dividend payout policy & Rejected \\
\hline H6: There is a significant positive relationship between firm size and dividend payout policy & Rejected \\
\hline $\begin{array}{l}\text { H7a: There is a significant negative relationship between institutional ownership and dividend payout } \\
\text { policy }\end{array}$ & Rejected \\
\hline $\begin{array}{l}\text { H7b: There is a significant positive relationship between managerial ownership and dividend payout } \\
\text { policy }\end{array}$ & Supported \\
\hline H7c. There is a significant negative relationship between free float ownership and dividend payout policy. & Rejected \\
\hline
\end{tabular}

On the other hand, it matches the justification of Al-Qahtani \& Ajina (2017) that the increase of managerial ownership leads to an opportunistic behavior in the company and to control this behavior, the board of directors decide to increase dividends, which matches the poor corporate governance environment in Egypt (EBRD, 2021), it also matches hypothesis $7 \mathrm{~b}$ and therefore it is accepted. This result is in line with a lot of previous studies such as Sakir \& Fadli (2014), Sindhu et al. (2016), Al-Qahtani and Ajina (2017) and Dhuhri and Diantimala (2018).

Model 2 did not show any difference in the results after excluding firms with negative equity. Thus, only $\mathrm{H} 1$ and $\mathrm{H} 7 \mathrm{~b}$ are accepted and all the other hypotheses are rejected.

Lastly in Model 3, leverage shows a significant negative relationship with the payout ratio, which means that $\mathrm{H} 4$ is accepted. This means that if a firm is already a payer, the amount of debts it has will influence its decision to increase or decrease dividends. This is consistent with the argument that the high cost of external financing in Egypt may prevent firms from increasing their dividends when they have high debt burden.

Table 8 provides a summary of the main results obtained as response to the research hypotheses.

\section{Conclusion}

This study investigates the determinants of payout policy in a developing market with poor corporate governance and a lot of economic downturns like Egypt which is lacking in the literature as most of previous studies mainly focus on developed market. 
This paper investigates the effect of profitability, free cash flow, investment opportunity, liquidity, leverage, firm size, managerial ownership, institutional ownership and free float ownership, on two dependent variables. First the dividend decisionor inother words the decision of whether to distribute dividends or not despite the quantity of dividends distributed. The second dependent variable which is the payout ratio shows the quantity of dividends to be distributed from the net income.

The results of the dividend decision show that only two variables were significant or in other words only investment opportunity and profitability are what determines the dividend decision of Egyptian firms and therefore, only $\mathrm{H} 1$ and $\mathrm{H} 2$ are accepted. These results describe that due to the economic crashes and downturns that the Egyptian market recently went through, the external sources of finance whether bank loans or capital market (stock issuance) are very restricted and costly, therefore, firms mainly depend on their internal sources in financing their investment opportunities and will not be able to payout dividend whenever that are deciding to go for new investments. Therefore, only mature profitable firms that have less investment opportunities are able to distribute dividends to shareholders.

As for the results of the payout ratio model, the results show that three variables influence the company's decision to increase or decrease dividends or the percentage of dividends to be paid out from the firm's earnings. These variables are: free cash flow, profitability and managerial ownership so $\mathrm{H} 1$ and H7b are supported but $\mathrm{H} 3$ is partially. We justified these results by explaining that due to the high financing cost, firms choose to keep free cash flow and decrease dividends to use it as source of financing and also the bad economic and political situation of the Egyptian market could lead firms to keep the free cash flow as a backup plan to any financial distress that could happen in the near future. So, firms choose to increase dividends only when they are mature and that realize high profits.

Moreover, the Egyptian market is characterized with its poor corporate governance and therefore, high managerial ownership represents a threat that managers could use the firms free cash flow to realize their own interest, therefore the board of directors could vote for lower dividends to control the opportunistic behavior of managers. As robustness checks when firms having extreme payout ratio were excluded and we included in the sample only dividend paying firms having payout ratio between 0 and 1 . We found that leverage has a significant negative relationship with the payout ratio and all the other variables showed an insignificant relationship with payout ratio and therefore, $\mathrm{H} 4$ is supported.

After reviewing these results, firms' managers should pay attention to their dividend policies and carefully focus on the determinants since a minor change in a firm's dividend payout policy may lower the investments on the company's shares. The same for investors they should be careful on these determinants 
when making their investment decision.

\section{Suggestion for Further Research and Limitations of the Study}

The quality of the study depends purely upon the accuracy, reliability and quality of secondary data. However, collecting financial data in Egypt was a challenge. So the main limitation for this research is the that due to unavailability of data, data was gathered from several sources which created inconsistency regarding the structure of the financial statements.

Finally we recommend that further research could consider studying more aspects of the dividend policy and specially behavioral factors which is nowadays the new focus of payout policy after Baker and Wurgler (2004) catering theory. These behavioral aspects could help better explaining the payout policy in a developing market like Egypt since they are characterized by noise and speculative trading behavior.

\section{Conflicts of Interest}

The authors declare no conflicts of interest regarding the publication of this paper.

\section{References}

Abdelsalam, O., \& El-Masry, A. (2008). The Impact of Board Independence and Ownership Structure on the Timeliness of Corporate Internet Reporting of Irish-Listed Companies. Managerial Finance, 34, 907-918.

https://doi.org/10.1108/03074350810915842

Abor, J., \& Bokpin, G. (2010). Investment Opportunities, Corporate Finance, and Dividend Payout Policy: Evidence from Emerging Markets. Studies in Economics and Finance, Emerald Group Publishing, 27, 180-194. https://doi.org/10.1108/10867371011060018

Afza, T., \& Mirza, H. H. (2010). Ownership Structure and Cash Flows as Determinants of Corporate Dividend Policy in Pakistan. International Business Research, 3, 210-221. https://doi.org/10.5539/ibr.v3n3p210

Ahmed, I. E. (2013). Factors Determining the Selection of Capital Budgeting Techniques. Journal of Finance and Investment Analysis, 2, 77-88.

Ahmed, I. E. (2015). Liquidity, Profitability and the Dividends Payout Policy. World Review of Business Research, 5, 73-85.

Al-Kayed, L. T. (2017). Dividend Payout Policy of Islamic vs Conventional Banks: Case of Saudi Arabia. International Journal of Islamic and Middle Eastern Finance and Management, 10, 117-128. https://doi.org/10.1108/IMEFM-09-2015-0102

Al-Malkawi, H. (2007). Determinants of Corporate Dividend Policy in Jordan: An Application of the Tobit Model. Journal of Economic and Administrative Sciences, 23, 44-70. https://doi.org/10.1108/10264116200700007

Al-Najjar, B., \& Kilincarslan, E. (2016). The Effect of Ownership Structure on Dividend Policy: Evidence from Turkey. Corporate Governance, 16, 135-161.

https://doi.org/10.1108/CG-09-2015-0129 
Al-Qahtani, T. H., \& Ajina, A. (2017). The Impact of Ownership Structure on Dividend Policy the Evidence from Saudi Arabia. Journal of Emerging Issues in Economics, Finance and Banking, 6, 2187-2202.

Amidu, M., \& Abor, J. (2006). Determinants of the Dividend Payout Ratio in Ghana. The Journal of Risk Finance, 7, 136-145. https://doi.org/10.1108/15265940610648580

Baker, H. K., Dewasiri, N. J., Yatiwelle Koralalage, W. B., \& Azeez, A. A. (2019). Dividend Policy Determinants of Sri Lankan Firms: A Triangulation Approach. Managerial Finance, 45, 2-20. https://doi.org/10.1108/MF-03-2018-0096

Baker, H. K., Farrelly, G. E., \& Edelman, R. B. (1985). A Survey of Management Views on Dividend Policy. Financial Management, 14, 78-84. https://doi.org/10.2307/3665062

Baker, M., \& Wurgler, J. (2004). A Catering Theory of Dividends. The Journal of Finance, 59, 1125-1165. https://doi.org/10.1111/j.1540-6261.2004.00658.x

Basri, H. (2019) Assessing Determinants of Dividend Policy of the Government-Owned Companies in Indonesia. International Journal of Law and Ma Management, 61, 530-541. https://doi.org/10.1108/IJLMA-09-2017-0215

Bhattacharya, S. (1979). Imperfect Information, Dividend Policy, and "The Bird in the Hand" Fallacy. Bell Journal of Economics, 10, 259-270. https://doi.org/10.2307/3003330

Bilel, H., \& Mondher, K. (2021). What Can Explain Catering of Dividend? Environment Information and Investor Sentiment. Journal of Economics and Finance, 45, 428-450. https://doi.org/10.1007/s12197-021-09540-0

Black, F. (1976). The Dividend Puzzle. Journal of Portfolio Management, 2, 5-8. https://doi.org/10.3905/jpm.1976.408558

Bokpin, G. (2011). Ownership Structure, Corporate Governance and Dividend Performance on the Ghana Stock Exchange. Journal of Applied Accounting Research, 12, 61-73. https://doi.org/10.1108/09675421111130612

Brennan, M. (1970). Taxes, Market Valuation and Corporate Financial Policy. National Tax Journal, 23, 417-427. https://doi.org/10.1086/NTJ41792223

Budagaga, A. R. (2020). Determinants of Banks' Dividend Payment Decisions: Evidence from MENA Countries. International Journal of Islamic and Middle Eastern Finance and Management, 13, 847-871. https://doi.org/10.1108/IMEFM-09-2019-0404

Budiarso, N. S., Subroto, B., Sutrisno, T., \& Pontoh, W. (2019). Dividend Catering, Life-Cycle, and Policy: Evidence from Indonesia. Cogent Economics \& Finance, 7, Article ID: 1594505 . https://doi.org/10.1080/23322039.2019.1594505

Byun, J., Kim, K., Liao, R., \& Pan, C. (2021). The Impact of Investor Sentiment on Catering Incentives around the World. Journal of International Financial Markets, Institutions and Money, 71, Article ID: 101285. https://doi.org/10.1016/j.intfin.2021.101285

Chazi, A., Theodossiou, A., \& Zantout, Z. (2018). Corporate Payout-Form: Investors' Preference and Catering Theory. Managerial Finance, 44, 1418-1433. https://doi.org/10.1108/MF-03-2018-0127

De Angelo, H., \& Deangelo, L. (2006). The Irrelevance of the MM Dividend Irrelevance Theorem. Journal of Financial Economics, 79, 293-315. https://doi.org/10.1016/j.jfineco.2005.03.003

Deng, L., Li, S., Liao, M., \& Wu, W. (2013). Dividends, Investment and Cash Flow Uncertainty: Evidence from China. International Review of Economics \& Finance, 27, 
112-124. https://doi.org/10.1016/j.iref.2012.09.005

Denis, D., \& Osobov, I. (2008). Why Do Firms Pay Dividends? International Evidence on the Determinants of Dividend Policy. Journal of Financial Economics, 89, 62-82. https://doi.org/10.1016/j.jfineco.2007.06.006

Dewasiri, N. J., \& Weerakoon, Y. K. B. (2016). Why Do Companies Pay Dividends? A Comment. Journal of Corporate Ownership and Control, 13, 443-453. https://doi.org/10.22495/cocv13i2c2p5

Dewasiri, N., Banda, Y., Azeez, A., \& Jayarathne, P. (2019). Determinants of Dividend Policy: Evidence from an Emerging and Developing Market. Managerial Finance, 45, 413-429. https://doi.org/10.1108/MF-09-2017-0331

Dhuhri, R., \& Diantimala, Y. (2018). The Influence of Institutional Ownership, Individual Ownership, and Managerial Ownership Toward Dividend Payout Ratio at Non-Financial Companies Registered in Indonesia Stock Exchange in 2012-2016. International Journal of Social Science and Economic, 3, 786-801.

Easterbrook, F. H. (1984). Two Agency-Cost Explanations of Dividends. The American Economic Review, 74, 650-659.

EBRD (2021). Financial Report 2017. https://www.ebrd.com/news/publications/financial-report/ebrd-financial-report-2017. $\underline{\mathrm{html}}$

ElBannan, M. A. (2020). Does Catering Behavior Persist? Evidence on Dividend Sentiment in Emerging Financial Markets. International Review of Economics \& Finance, 69, 350-373. https://doi.org/10.1016/j.iref.2020.06.016

Fairchild, R. (2010). Dividend Policy, Signalling and Free Cash Flow: An Integrated Approach. Managerial Finance, 36, 394-413. https://doi.org/10.1108/03074351011039427

Fama, E. F., \& French, K. R. (2001). Disappearing Dividends: Changing firm Characteristics or Lower Propensity to Pay? Journal of Financial Economics, 60, 3-43. https://doi.org/10.1016/S0304-405X(01)00038-1

Garengo, P., Nudurupati, S., \& Bititci, U. (2007). Understanding the Relationship between PMS and MIS in SMEs: An Organizational Life Cycle Perspective. Computers in Industry, 58, 677-686. https://doi.org/10.1016/j.compind.2007.05.006

Glen, J. D., Karmokolias, Y., Miller, R. R., \& Shah, S. (1995). Dividend Policy and Behavior in Emerging Markets: To Pay or Not to Pay. The World Bank.

Gordon, M. J. (1959). Dividends, Earnings, and Stock Prices. Review of Economics and Statistics, 41, 99-105. https://doi.org/10.2307/1927792

Gul, F. A., Krishnamurti, C., Shams, S., \& Chowdhury, H. (2020). Corporate Social Responsibility, Overconfident CEOs and Empire Building: Agency and Stakeholder Theoretic Perspectives. Journal of Business Research, 111, 52-68.

https://doi.org/10.1016/j.jbusres.2020.01.035

Harackiewicz, J., Barron, K., Pintrich, P. R., Elliot, A., \& Thrash, T. (2002). Revision of Achievement Goal Theory: Necessary and Illuminating. Journal of Educational Psychology, 94, 638-645. https://doi.org/10.1037/0022-0663.94.3.638

Imamah, N., Lin, T., Suhadak, Handayani, S., \& Hung, J. (2019). Islamic Law, Corporate Governance, Growth Opportunities and Dividend Policy in Indonesia Stock Market. Pacific-Basin Finance Journal, 55, 110-126. https://doi.org/10.1016/j.pacfin.2019.03.008

Islam, S. M. T., Ghosh, R., \& Khatun, A. (2021). Slack Resources, Free Cash Flow and 
Corporate Social Responsibility Expenditure: Evidence from an Emerging Economy. Journal of Accounting in Emerging Economies, 11, 533-551. https://doi.org/10.1108/JAEE-09-2020-0248

Jabbouri, I. (2016). Determinants of Corporate Dividend Policy in Emerging Markets: Evidence from MENA Stock Markets. Research in International Business and Finance, 37, 283-298. https://doi.org/10.1016/j.ribaf.2016.01.018

Jensen, M. (1986). Agency Costs of Free Cash Flow, Corporate Finance, and Takeovers. American Economic Review, 76, 323-329.

Jensen, M. C., \& Meckling, W. (1976). Theory of the Firm: Managerial Behavior, Agency Costs and Capital Structure. Journal of Financial Economics, 3, 305-360. https://doi.org/10.1016/0304-405X(76)90026-X

Kania, S. L., \& Bacon, F. W. (2005). What Factors Motivate the Corporate Dividend Decision? ASBBS E-Journal, 1, 97-107.

Khan, N. U., Burton, B. M., \& Power, D. M. (2011). Managerial Views about Dividend Policy in Pakistan. Managerial Finance, 37, 953-970. https://doi.org/10.1108/03074351111161600

Khana, Z., Ramakrishnanb, S., Malikc, M. F., \& Ullahd, M. (2020). Impact of Growth Opportunities on Dividend Policy: Evidence on the Role of CEO Duality in the Emerging Economy of Pakistan. International Journal of Innovation, Creativity and Change, 11, 783-794.

Kumar, B. R., \& Waheed, K. A. (2015). Determinants of Dividend Policy: Evidence from GCC Market. Accounting and Finance Research, 4, 17-29. https://doi.org/10.5430/afr.v4n1p17

Lintner, J. (1956) Distribution of Incomes of Corporations among Dividends, Retained Earnings, and Taxes. American Economic Review, 46, 97-113.

Majluf, N., \& Myers, S. (1984). Corporate Financing and Investment Decisions When Firms Have Information That Investors Do Not Have. Journal of Financial Economics, 13, 187-221. https://doi.org/10.1016/0304-405X(84)90023-0

Mehdi, M., Sahut, J. M., \& Teulon, F. (2017). Do Corporate Governance and Ownership Structure Impact Dividend Policy in Emerging Market during Financial Crisis? Journal of Applied Accounting Research, 18, 274-297. https://doi.org/10.1108/JAAR-07-2014-0079

Metwally, A. H., \& Darwish, O. (2015). Evidence of the Over Confidence Bias in the Egyptian Stock Markets in Different Market States. The Business and Management Review, 6, 178-198.

Miller, M. H., \& Modigliani, F. (1961). Dividend Policy, Growth, and the Valuation of Shares. The Journal of Business, 34, 411-433. https://doi.org/10.1086/294442

Myers, S. (1984). The Capital Structure Puzzle. Journal of Finance, 39, 574-592. https://doi.org/10.1111/j.1540-6261.1984.tb03646.x

Neves, M. E. D. (2017). Payout and Firm's Catering. International Journal of Economics \& Business Administration (IJEBA), 4, 104-132. https://doi.org/10.35808/ijeba/145

O'Connor, T., \& Byrne, J. (2015). Governance and the Corporate Life-Cycle. International Journal of Managerial Finance, 11, 23-43.

https://doi.org/10.1108/IJMF-03-2013-0033

OECD (2020). The Covid-19 Crisis in Egypt.

https://www.oecd.org/mena/competitiveness/The-Covid-19-Crisis-in-Egypt.pdf 
Ozuomba, C. N., Anichebe, A. S., \& Okoye, P. V. C. (2016). The Effect of Dividend Policies on Wealth Maximization-A Study of Some Selected PLCS. Cogent Business \& Management, 3, Article ID: 1226457. https://doi.org/10.1080/23311975.2016.1226457

Panigrahi, A. K. (2013). Liquidity Management of Indian Cement Companies: A Comparative Study. IOSR Journal of Business and Management, 14, 49-61. https://doi.org/10.9790/487X-1454961

Patra, T., Poshakwale, S., \& Kean, O. (2012). Determinants of Corporate Dividend Policy in Greece. Applied Financial Economics, 22, 1079-1087.

https://doi.org/10.1080/09603107.2011.639734

Ramadan, I. Z. (2015). The Jordanian Catering Theory of Dividends. International Journal of Business and Management, 10, 226-230. https://doi.org/10.5539/ijbm.v10n2p226

Ranajee, R., \& Pathak, R. (2018). Corporate Cash Holding during Crisis and Beyond: What Matters the Most. International Journal of Managerial Finance, 15, 492-510. https://doi.org/10.1108/IJMF-03-2018-0085

Rozeff, M. (1982). Growth, Beta and Agency Costs as Determinants of Dividend Payout Ratios. Journal of Financial Research, 5, 249-259. https://doi.org/10.1111/j.1475-6803.1982.tb00299.x

Sakir, A., \& Fadli, M. (2014). Influence of Managerial Ownership, Debt Policy, Profitability, Firm Size, and Free Cash Flow on Dividend Policy: A Study in Indonesian Manufacturing Industries. Delhi Business Review, 15, 15-22. https://doi.org/10.51768/dbr.v15i1.151201402

Schmidt, A. F., \& Finan, C. (2018). Linear Regression and the Normality Assumption. Journal of Clinical Epidemiology, 98, 146-151. https://doi.org/10.1016/j.jclinepi.2017.12.006

Setiawan, D., Bandi, B., Phua, L., \& Trinugroho, I. (2016). Ownership Structure and Dividend Policy in Indonesia. Journal of Asia Business Studies, 10, 230-252. https://doi.org/10.1108/JABS-05-2015-0053

Sindhu, M. I., Hashmi, S. H., \& Ul Haq, E. (2016). Impact of Ownership Structure on Dividend Payout in Pakistani Non-Financial Sector. Cogent Business \& Management, 3, Article ID: 1272815. https://doi.org/10.1080/23311975.2016.1272815

Takmaz, S., Evrim Mandaci, P., \& Durukan, M.B. (2020). The Impact of Catering Incentives on the Dividend Policy: Evidence from Turkish Firms. Managerial Finance, 47, 897-914. https://doi.org/10.1108/MF-04-2020-0215

Thanatawee, Y. (2011). Life-Cycle Theory and Free Cash Flow Hypothesis: Evidence from Dividend Policy in Thailand. International Journal of Financial Research, 2, 52-60. https://doi.org/10.5430/ijfr.v2n2p52

Trabelsi, D., Aziz, S., \& Lilti, J.-J. (2019). A Behavioral Perspective on Corporate Dividend Policy: Evidence from France. Corporate Governance, 19, 102-119. https://doi.org/10.1108/CG-02-2018-0077

Wahjudi, E. (2019). Factors Affecting Dividend Policy in Manufacturing Companies in Indonesia Stock Exchange. Journal of Management Development, 39, 4-17. https://doi.org/10.1108/JMD-07-2018-0211

Walsh, J. P., Kress, J. C., \& Beyerchen, K. W. (2005). Promises and Perils at the Bottom of the Pyramid. Administrative Science Quarterly, 50, 473-482. https://doi.org/10.2189/asqu.2005.50.3.473 
A.-G. Heba et al.

Yusof, Y., \& Ismail, S. (2016). Determinants of Dividend Policy of Public Listed Companies in Malaysia. Review of International Business and Strategy, 26, 88-99.

https://doi.org/10.1108/RIBS-02-2014-0030 


\section{Appendix}

List of excluded companies from our sample:

Abu Dhabi Islamic Bank - Egypt

Al Baraka Bank Egypt

Al Tawfeek Leasing Company-A.T.LEASE

Alexandria National Company for Financial Investment

Arab Moltaka Investments Co

Arabia Investments Holding

Aspire Capital Holding For Financial Investments

B Investments Holding

Banque Du Caire

Belton Financial Holding

CI Capital Holding For Financial Investments

Certificates Of Odin Egyptian Equity Investment Fund-KASAB

Citadel Capital - Common Shares

Citadel Capital - Preferred Shares

Commercial International Bank (Egypt)

Contact Financial Holding

Credit Agricole Egypt

Delta Insurance

EDRs Of Al Salam Holding Company

EGX 30 INDEX ETF

Egyptian Arabian (cmar) Securities Brokerage EAC

Egyptian Financial Group-Hermes Holding Company

Egyptian Gulf Bank

Egyptian Kuwaiti Holding

Egyptian Kuwaiti Holding-EGP

Egyptians Real Estate Fund Certificates

El Ahli Investment and Development

El Kahera El Watania Investment

El Orouba Securities Brokerage

Export Development Bank of Egypt (EDBE)

Faisal Islamic Bank of Egypt - In EGP

Faisal Islamic Bank of Egypt - In US Dollars

Gadwa For Industrial Development

Grand Investment Capital

Housing \& Development Bank

International Company For Leasing (IncoLEASE)

Mohandes Insurance

Naeem Holding 


\section{Continued}

National Bank Of Kuwait - Egypt - NBK

ODIN Investments

Orascom Financial Holding

Osool ESB Securities Brokerage

Pioneers Properties For Urban Development(PREDCO)

Prime Holding

Qatar National Bank Alahly

Raya Holding For Financial Investments

Saudi Egyptian Investment \& Finance

Saudi Egyptian Investment \& Finance \$

Societe Arabe Internationale De Banque (SAIB)

Suez Canal Bank S.A.E

Fawry For Banking Technology And Electronic Payment

Integrated Diagnostics Holdings plc

Iron And Steel for Mines and Quarries

Rights Issue Of El Obour Real Estate Investment-2 